\title{
The Farmer Response to Conservation Agriculture in Monze, Zambia
}

\author{
Joseph T. Mwale, Idani Lichilo, Mutinta Muyangwa
}

\begin{abstract}
Conservation agriculture is promoted as a sustainable agricultural practice in Zambia in the wake of increasing shifts in rainfall patterns along with land degradation. Yet the practice has been partially adopted by most small-scale farmers in spite of the well-established socio-economic benefits. As part of the scientific endeavour to understand the socio-dynamics of conservation agriculture, this paper assesses the farmer response to the emergent agricultural practice under the hypothesis that adoption of the practice as promoted by agricultural development agencies is a pragmatic realization of a disrupted agro-ecological system under the increasing influence of socio-economic and bio-physical factors. Using a combination of principal components analysis and logistic regression, it has been established that there is a positive farmer response to conservation farming in view of the perceived negative effects of climate variability and the high utility derived from engaging in the practice. The most significant factors influencing the farmer response are climate variability and income status of the farmer among other factors including extension service delivery and labour intensity. The analysis leads to a logical conclusion that the probability that a farmer in Manungu agricultural block will adopt conservation farming is $40 \%$ if there is poor extension service delivery. It is, therefore, recommended for further research and agricultural development policy that cost-effectiveness should be a central feature of the design of conservation farming technologies for the smallholder farmers in light of the low income status of the farmers; and that pragmatic approaches to extension service delivery should be engaged to ensure successful adoption of conservation farming technologies.
\end{abstract}

Index terms-Farmer response, Conservation agriculture, Monze, Zambia

\section{INTRODUCTION}

In the context of global environmental change, conservation agriculture (CA) has emerged as a sustainable agricultural practice against a backdrop of low agricultural productivity due to climate variability and environmental degradation. FAO [1] defines $\mathrm{CA}$ as an approach to managing agro-ecosystems for improved and sustained productivity, increased profits and food security while preserving and enhancing the resource base and the environment. Haggblade and Tembo [2] gave a historical account of the emergence of

Joseph T. Mwale, School of Agriculture and Natural Resources, Mulungushi University, Kabwe, Zambia, Phone/ Mobile No. +260973777940, (e-mail: jt_mwale@yahoo.com).

Idani Lichilo, School of Agriculture and Natural Resources, Mulungushi University, Kabwe, Zambia, Phone/ Mobile No. +260977301346, (e-mail: ilichilo@yahoo.co.uk).

Mutinta Muyangwa, School of Agriculture and Natural Resources, Mulungushi University, Kabwe, Zambia, Phone/ Mobile No. +260971664369, (e-mail: mutintamuyangwa@yahoo.com). conservation agriculture in the United States of America out of ecological and economic hard-ships due to the catastrophic droughts in the 1930s and rising fuel prices during the 1970s. Arslan et al. [3] noted that the agricultural practice has been promoted to smallholder farmers in Sub-Saharan Africa by several international and national organizations to address the problems of soil degradation and low agricultural productivity and realize widespread sustainable agricultural intensification. Mazvimavi et al. [4] highlighted the technical potential of conservation agriculture in increasing productivity by improving water retention capacity, fixing nitrogen and enabling timely planting. The principles guiding the promotion of conservation agriculture were postulated by FAO [5] to include minimum mechanical soil disturbance, permanent organic soil cover and crop rotation. These principles were based on realization of soil degradation thought to be caused by intensive tillage, lack of soil cover and burning of crop residue. Benites [6] and Derpsch [7] earlier identified a major driver of land degradation in intensive soil preparation by hoe or plough combined with removal or burning of crop residues leaving the soil exposed to climatic hazards such as rain, wind and sun.

In this introductory section of the paper, the state of knowledge about conservation agriculture promoted by agricultural development agencies as a climate-smart agricultural practice is reviewed revolving around the perception of conservation farming by the scientific community, development agencies and the farmers as well as the determinants of adoption of the conservation agricultural technologies. Tisdell [8] exposited three dimensions of the concept of conservation agriculture (CA). The first dimension is protection of the natural resources base upon which agricultural productivity depends, while the second dimension is conservation of biodiversity of species on which agriculture depends; and the third dimension is adoption of agricultural practices which help to conserve biodiversity in general. These three conceptual definitions all point to the need to sustain the ecological integrity of an agro-ecosystem. It is in this perspective that Smyth et al. [9] considered conservation agriculture as part of sustainable land management which consisted in integrating socio-economic principles with environmental concerns by combining technologies, policies and activities with a view to simultaneously maintaining or enhancing productivity, reducing production risks, preventing degradation of soil and water quality, and ensuring economic viability and social acceptability. 
Several techno-cultural practices of soil and water conservation have been developed and promoted in various parts of the world. Derpsch and Friedrich [10] revealed that Conservation agriculture (CA) systems, particularly minimum and zero tillage systems, had been developed and successfully adopted by farmers in the United States of America, Latin America, Europe and certain parts of South Asia as a means to improving soil conservation, reducing labour and energy needs and ultimately increasing yield levels. In Sub-Saharan Africa (SSA), conservation agriculture is reported for Zambia as consisting in reducing tillage without soil inversion, digging permanent planting basins, ripping the soil, leaving crop residues on the field, rotating cereals with legumes and dry season land preparation [11]. In the Philippines in Asia, Cramb et al. [12] reported that while the conservation farming projects promoted a suite of agroforestry and technologies directed at soil conservation and fertility management, contour hedgerows and contour bunds were the key soil conservation technologies recommended.

The response of farmers to conservation agriculture is measured by the rate of adoption of the practice, and the decision to adopt is a function of several factors including perception. There appears to be a positive correlation between perception of increased climate variability and the use of conservation farming in Zambia, where adoption of CA was, however, reported to be relatively limited and unstable [2]. In the Philippines, it was reported that many of the adopters cited control of soil erosion and increased soil fertility as the main reasons for adoption, while others were merely following recommendations or directives [12]. Morris et al. [13] postulated that farmers were likely to adopt a tillage system that offered them flexibility in a range of cropping and soil conditions, allowing them to establish crops successfully and as economically as possible, while maintaining or improving productivity and profitability. In spite of the overwhelming novelty of conservation agriculture, adoption of the practice among farmers in certain locations is seemingly low. FAO [14] and Dumanksi et al. [15] attributed the low momentum for CA in SSA to the traditionally narrow focus of CA on minimum and no-tillage systems. Rockström et al. [16] also observed that there was very limited evidence of yield improvements from conservation farming practices in semi-arid and dry sub-humid smallholder savannah agro-ecosystems. In certain contexts, conservation agriculture may be perceived as a risky new investment with typically no insurance and a time lag of about four years in the accrual of benefits to those engaged in the practice [17] and [18]. Arslan et al. [3] reviewed several scholarly works on the determinants of adoption of CA and identified such factors as labour requirements, agro-ecological constraints on soils, climate and the opportunity cost of incorporating post-harvest crop residues as some of the drivers of adoption of conservation agriculture. Other drivers highlighted include lack of infrastructure, insufficient involvement of farmers in the process, existing livestock management norms, imperfect input and credit markets and land tenure as some of the socio-economic and institutional factors limiting wide-spread adoption of CA in Southern Africa. In view of the foregoing, the farmer response to emergent concepts in agriculture is dependent on the social-cultural and bio-physical settings of the farmers. Studying coffee management adoption in Colombia, Bravo-Monroy et al. [19] noted that it entailed an understanding of social, political, economic, demographic, technological, cultural and biophysical factors that directly or indirectly influence decisions at the agro-ecosystem scale. Other scholars [20] have also emphasized understanding social factors at the farm level in the approach to providing better insight in what processes are important in the decision making process of a management adoption.

Conservation agriculture has been partially adopted by most small scale farmers in Zambia in spite of the known socio-economic benefits of the practice. The farmer response to conservation agriculture has not been widely investigated at a local scale, and this paper is motivated by the realization from literature that rigorous documentation of successes, failures and challenges related to conservation agriculture adaptation and adoption was still rare, especially outside of South America; and that most existing case studies did not rely on a unified systemic analytical framework, and demonstrated a strong bias towards emphasizing what was going well, overlooking process issues and problems encountered.

As part of the scientific endeavour to understand the socio-dynamics of conservation agriculture, this paper assesses the farmer response to the emergent agricultural practice in the Zambian context by determining the farmer response to conservation agriculture in the Manungu agricultural block; identifying the key factors influencing the farmer response; and quantifying the probability that a farmer in Manungu agricultural block will adopt conservation farming. Thus, the paper is organized into five main sections. Following the introduction in which the state of knowledge about the subject is reviewed, the methodology is presented in section II, which is followed by the results and discussion in Sections III and IV respectively. The concluding remarks with recommendations for further research and policy direction are given in Section V.

\section{METHODOLOGY}

\section{A. Conceptual Framework}

This research is founded within the theoretical framework of production of space [21] viewed as a triad of perceived space, conceptualized space and pragmatic space. "Perceived space embraces production modes and the particular locations and spatial sets characteristic of each social formation; conceptualized space is delineated by scientists or planners with knowledge and power; and pragmatic space embodies the daily experiences and routines [19]." Based on production of social space, it is theorized herein that adoption of conservation farming as promoted by agricultural development agencies in Manungu agricultural block, Zambia is a pragmatic realization of a disrupted agro-ecological system under the increasing influence of 
World Journal of Research and Review (WJRR)

\section{ISSN: 2455-3956, Volume-3, Issue-2, August 2016 Pages 68-73}

socio-economic and bio-physical factors. The conceptual framework for the analysis of the farmer response to CA in Zambia is illustrated in Fig. 1.

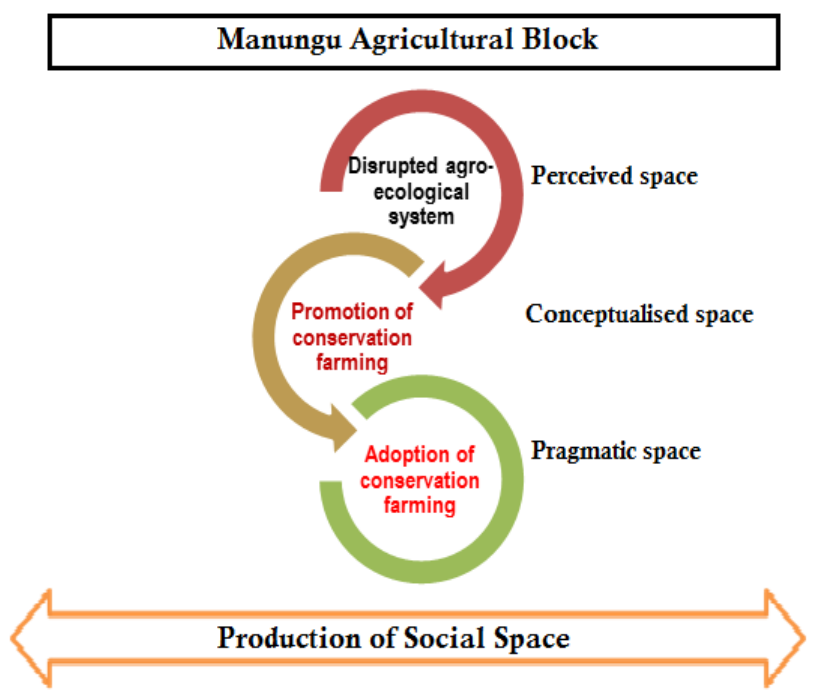

Fig. 1: Conceptual framework for analysis of farmer response to $\mathrm{CA}$ in Monze, Zambia

\section{B. Study Area}

The spatial reference for the analysis is the Manungu agricultural block, which is a local area in Zambia. Zambia is itself located within Sub-Saharan Africa (SSA) in the Southern African region. The geographical co-ordinates of the country are latitudes $08^{\circ}$ and $18^{\circ}$ South of the Equator and between longitudes $21^{\circ}$ and $38^{\circ}$ East of the Greenwich Meridian. The study area is located within Monze district in the Southern province of Zambia as shown in Fig.2. The area also occurs within Agro-ecological region II of Zambia, which supports a wide range of agricultural crop and livestock production.

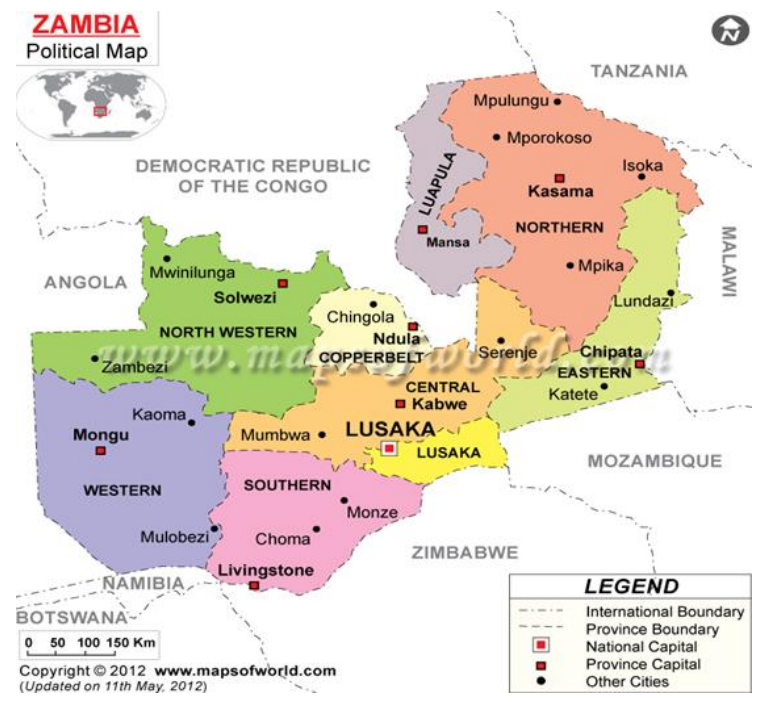

Fig.2. Map of Zambia (source: www.mapsofworld.com)

\section{Sampling Design and Data Collection}

The sampling design considered appropriate for this case study is multi-stage sampling of the Manungu agricultural block for primary data collection using structured interviews. The agricultural block is made up of six agriculture camps from which two camps are purposively selected for random sampling of the smallholder farmers. A convenient sample size of 100 farmers is drawn from the population of smallholder farmers that are registered with the Department of Agriculture. A list of variables for data collection is presented in Table I.

Table I: Variables for the analysis of farmer response to conservation agriculture in Monze, Zambia

\begin{tabular}{l|l}
\hline \multicolumn{1}{c}{ Parameter } & \multicolumn{2}{l}{ Variables } \\
\hline Farmer & 1) Gender \\
response to CA & $\begin{array}{l}\text { 2) Age } \\
\text { 3) Attitude } \\
\text { 4) Utility } \\
\text { 5) Participation } \\
\text { response }\end{array}$ \\
& 6) Extension service delivery \\
& 8) Income status \\
& 9) Labour intensity
\end{tabular}

\section{Data Analysis}

In line with the research objectives, the methods of data analysis that are considered appropriate include principal components analysis, correlation relation analysis, and regression analysis.

\section{Principal Components Analysis (PCA)}

Principal components analysis (PCA) is herein used to determine the farmer response to conservation farming in Manungu agricultural block by gender, age, attitude, utility and participation. PCA is defined in mathematical statistics as an orthogonal linear transformation that transforms a set of observations of possibly correlated variables into a set of values of linearly uncorrelated variables called principal components (PCs). The $\mathrm{PC}$ is computed to determine the tendency of two random variables to vary together. The covariance is expressed as:

$$
\operatorname{cov}(X, Y)=\sum_{i=1}^{N} \frac{\left(x_{i}-\bar{x}\right)-\left(y_{i}-\bar{y}\right)}{N}
$$

Where, $\bar{x}$ is mean $(\mathrm{X})$, and $\bar{y}$ is mean (Y). PCA seeks a linear combination of variables such that the maximum variance is extracted from the variables. The transformation in PCA is such that the first principal component has the largest possible variance in the data, and each succeeding component in turn has the highest variance possible under the constraint that it is orthogonal to the preceding components. 


\section{Correlation Analysis}

The Spearman's rank correlation test is used in this research to identify the factors significantly influencing the farmers' response to conservation farming in Manungu agricultural block. In statistical terms, the Spearman's correlation coefficient is a nonparametric measure of statistical dependence between two variables. The Spearman's test statistic, $r_{S}$ is given by:

$$
r_{S}=1-\frac{6 \sum d_{i}^{2}}{n\left(n^{2}-1\right)}
$$

Where, $d_{i}$ is the difference between the two ranks of each observation, and $n$ is the number of observations. The sign of the Spearman correlation indicates the direction of association between the independent variable $(\mathrm{X})$ and the dependent variable (Y). If $\mathrm{Y}$ tends to increase when $\mathrm{X}$ increases, the Spearman correlation coefficient is positive. If $\mathrm{Y}$ tends to decrease when $\mathrm{X}$ increases, the Spearman correlation coefficient is negative. A Spearman correlation of zero indicates that there is no tendency for $\mathrm{Y}$ to either increase or decrease when $\mathrm{X}$ increases. If there are no repeated data values, a perfect Spearman correlation of +1 or -1 occurs when each of the variables is a perfect monotone function of the other.

\section{Regression Analysis}

A logit regression model is used in this research to estimate the probability that a farmer in Manungu agricultural block will adopt conservation farming based on the identified determinants. Based on the hypothesized non-linear relationships between the dependent and independent variables, a logistic function is applied to the non-linear relationship using logarithmic transformation. The mathematical specification of the logit regression model is given by:

$$
\operatorname{logit}(y)=\ln \left(\frac{p}{1-p}\right)=\alpha+\beta_{1} \chi_{1}+\cdots+\beta_{k} \chi_{k}
$$

Where, $\mathrm{p}$ is the probability of the interested outcome $\mathrm{y}, \chi$ is the explanatory variable, $\alpha$ is the regression coefficient, and $\beta$ is the intercept. The logit regression model estimates the odds of occurrence or non-occurrence of an event outcome. While a linear regression model uses the R-squared to measure the goodness of fit of the data to the regression line, a pseudo R-squared is used in logit regression. The response variable for the logit regression in this research is participation in CA, which is a dichotomous variable with a "Yes" or "No" binary state. The explanatory variables are the categorical variables including extension service delivery, income, climate variability and labour intensity.

\section{RESULTS}

\section{A. Farmer Response to CA in Monze}

With reference to the first objective of the research aimed at determining the response of farmers to conservation agriculture in the Manungu agricultural block, principal components analysis was applied to the data on gender, age, attitude, utility and participation. The results of the data analysis are presented in Table II.

Table II: PCA of farmer response to CA in Monze, Zambia

\begin{tabular}{l|cc}
\hline \multicolumn{1}{l}{ Variable } & \multicolumn{2}{c}{ Principal Component } \\
& PC1 & PC2 \\
\hline Attitude & 0.727 & \\
Utility & 0.586 & 0.485 \\
Gender & -0.569 & 0.493 \\
Participation & -0.340 & \\
Age & & -0.816 \\
\hline
\end{tabular}

From Table II, the first principal component appears to be strongly correlated with two of the original variables. It can be seen that the first principal component increases with increasing attitude and utility scores suggesting that the two variables vary together. If the attitude score increases, then the utility score tends to increase as well. This component can be viewed as a composite index of farmer response to conservation farming. Furthermore, it can be observed that the first principal component correlates most strongly with attitude based on the correlation of 0.727 . The results further indicate that the second principal component increases with gender and utility, but age is negatively correlated with this component. This component can be viewed as a measure of how poor the farmer response is to conservation farming on the basis of age.

\section{B. Determinants of Farmer Response to CA}

The Spearman's correlation test was run to assess the relationship between farmer participation in $\mathrm{CA}$ and extension service delivery, income status, climate variability and labour intensity of CA among several factors. Based on a sample of 100 farmers, the results of analysis presented in Table III show that there is a positive correlation between farmer participation in CA and extension service delivery even though the correlation is weak. The correlation $\left(r_{\mathrm{s}}=\right.$ $0.149)$ is statistically significant $(p=0.140)$ against the null hypothesis that there was no significant correlation. The test further yielded a negative correlation between participation in $\mathrm{CA}$ and each of the independent variables including income status, climate variability and labour intensity of the practice. 
Table III: Determinants of farmer participation in CA in Manungu agricultural block

\begin{tabular}{l|lcl}
\hline $\begin{array}{l}\text { Dependent } \\
\text { variable }\end{array}$ & $\begin{array}{l}\text { Independent } \\
\text { variable }\end{array}$ & $\begin{array}{l}\text { Spearman's } \\
\text { correlation } \\
\text { coefficient }\end{array}$ & $\begin{array}{l}\text { P-value } \\
\text { statistic }\end{array}$ \\
\hline $\begin{array}{l}\text { Participation } \\
\text { in CA }\end{array}$ & $\begin{array}{l}\text { Extension service } \\
\text { delivery } \\
\text { Income status }\end{array}$ & 0.149 & 0.140 \\
& $\begin{array}{l}\text { Climate variability } \\
\text { Labour intensity of }\end{array}$ & -0.115 & 0.267 \\
& CA & 0.081 & 0.382 \\
& La & 0.422 \\
\hline
\end{tabular}

\section{Probability of CA Adoption}

A logit regression model is used to estimate the probability of adopting conservation farming in Manungu agricultural block by farmers based on extension service delivery, income status, climate variability and labour intensity of CA among several factors. Thus, a logistic function was applied to the hypothesized non-linear relationships between the dependent and independent variables using logarithmic transformation. The regression statistics are given in Table 5.

Table 5: Logistic regression of farmer participation in CA in Manungu agricultural block

\begin{tabular}{l|ccccc}
\hline \multicolumn{1}{l}{$\begin{array}{l}\text { Explanatory } \\
\text { variables }\end{array}$} & $\boldsymbol{\beta}$ & \multicolumn{5}{c}{ Regression statistics } \\
\hline Extension & -0.626 & 0.496 & 1.591 & 0.207 & 0.535 \\
service delivery & & & & & \\
Income status & 0.453 & 0.498 & 0.828 & 0.363 & 1.573 \\
Climate & 0.461 & 0.487 & 0.895 & 0.344 & 1.585 \\
variability & & & & & \\
Labour intensity & 0.310 & 0.486 & 0.407 & 0.523 & 1.364 \\
Constant & -1.331 & 0.619 & 4.616 & 0.032 & 0.264 \\
\hline
\end{tabular}

Based on the computed regression statistics, a mathematical specification of the resultant logit regression model is given by:

$$
P_{C F \text { Adoption }}=-1.331-0.626 E+0.4531+0.461 C+0.310 L
$$

Where, $\quad P$ is the probability of adopting CA, $E$ is extension service delivery, $I$ is income status of the farmer, $C$ is climate variability and $L$ is labour intensity of CA. The logit regression model predicts that the probability that a farmer in Manungu agricultural block will adopt conservation farming is $45 \%, 46 \%$ and $30 \%$ in view of income status of the farmer, climate variability and labour intensity of CA respectively. The probability that a farmer will not adopt conservation farming is $60 \%$ in view of poor extension service delivery. The regression outputs were validated with the use of the Wald hypothesis test. In the context of logistic regression, the Wald test is used to determine whether a certain predictor variable is significant or not under the null hypothesis of the corresponding coefficient being zero. In this regard, the null hypothesis is rejected in favour of the alternative hypothesis stating that the regression coefficients are not equal to zero.

\section{DISCUSSION}

A burgeoning human population is a daunting challenge for the 21 st century as the world ponders on how to feed 9 billion people in 2050. This challenge is compounded by global climate change that is substantially disrupting the functionality of various social-ecological systems. In this paper, it has been demonstrated that climate variability, particularly rainfall variability, is a key determinant of farmer adoption of conservation agriculture. In the soil-plant-atmosphere continuum, the water required by the plant is held in the soil and is drawn by the plant using solar energy from the atmosphere. Thus, variability in the atmospheric processes that bring about weather and climate along with changes in agricultural land use influence the availability of water for optimum growth and biological productivity of plants. In view of climate variability, conservation agriculture is aimed at conserving water and soil fertility for optimum plant growth. In the perspective of production of social space, the farmer response to conservation farming is met with a positive attitude based on a social construct of perceived space and the utility derived from the potentially improved agricultural productivity if CA is engaged. This is because the outcome of a distorted interaction between a farmer and an agro-ecosystem on account of climate variability is the inevitable reality of low agricultural productivity which leads to persistent hunger. Along with climate variability, income status of the farmer and labour intensity of CA influenced the probability that a farmer would adopt conservation farming. This is because low income status may constrain a farmer to meet the costs associated CA such as purchase of herbicides. Herbicides are particularly essential to militating against the high labour intensity of the weeding operation associated with CA. An interesting result was obtained for the influence of extension service delivery on CA. It was found that a farmer was highly unlikely to adopt CA if there was poor extension service delivery. This speaks directly to the social constructs of conceptual space and pragmatic space. The Agriculture extension service conceptualizes $\mathrm{CA}$ as beneficial to sustainable land and water management for agriculture, and the farmer response to the promoted practice depends on a pragmatic mode of delivery of the CA technologies to the farmer.

\section{CONCLUSION}

This research theorized that adoption of conservation agriculture as promoted by agricultural development agencies in Manungu agricultural block was a pragmatic realization of a disrupted agro-ecological system under the increasing influence of socio-economic and bio-physical factors. The analysis has revealed a correlation between the farmer response to $\mathrm{CA}$ and the determinants including extension service delivery, income status, climate variability and labour intensity among several factors. There is a positive farmer response to conservation agriculture in Manungu agricultural block, Monze in view of the perceived negative effects of climate variability and the high utility derived from engaging in the practice. The most significant factors influencing the 
farmer response to conservation agriculture in Manungu agricultural block are climate variability and income status of the farmer. Based on these determinants, the probability that a farmer in Manungu agricultural block will adopt conservation farming is $40 \%$ if there is poor extension service delivery. In view of these findings, it can be recommended for further research and agricultural development policy that cost-effectiveness should be a central feature of the design of conservation agricultural technologies for the smallholder farmers in light of the low income status of the farmers; and pragmatic approaches to extension service delivery should be engaged to ensure successful adoption of conservation agricultural technologies.

\section{ACKNOWLEDGMENT}

This research was made possible through shared knowledge, resources and support from a lot of people in different places. A special tribute of gratitude be paid to the farmers of Manungu Agricultural Block in Monze district of Zambia for freely participating in the structured interviews. Further acknowledgments are extended to the Department of Agriculture for enabling the process of data collection in their community of practice. Most of all, the financial support rendered to the team by the School of Agriculture and Natural Resources at Mulungushi University is duly acknowledged.

\section{REFERENCES}

[1] FAO. Conservation Agriculture. Food and Agriculture Organization of the United Nations. 2015, http://www.fao.org/ag/ca/1a.html.

[2] Haggblade S., Tembo G. Conservation Farming in Zambia International Food Policy Research Institute (IFPRI), Washington, DC. 2003, EPTD Discussion Paper 108.

[3] Arslan A., McCarthy N., Lipper L., Asfaw S., Cattaneo A. Adoption and Intensity of Adoption of Conservation Farming Practices in Zambia. Journal of Agriculture, Ecosystems and Environment. 2014 Vol. 187, 72-86.

[4] Mazvimavi K., Nyathi P., Murendo C. Conservation Agriculture Practices and Challenges in Zimbabwe. International Crops Research Institution for the Semi-Arid Tropics (ICRISAT), Bulawayo. 2011.

[5] FAO. Principles and Benefits of CA. 2012 http://www.fao.org/ag/ca/index.html..

[6] Benites J. Overcoming Constraints in Adoption of Conservation Tillage Practices. Proceedings from an International Workshop on Conservation Tillage for Sustainable Agriculture, Harare, 22-27 June. Part II. Annexes. Deutsche Gesellschaft, GTZ, Eschborn, Germany. 1998, 219-226.

[7] Derpsch R. Historical Review of No-tillage Cultivation of Crops. Proceedings from an International Workshop on Conservation Tillage for Sustainable Agriculture, Harare, 22-27 June. Part II. Annexes. Deutsche Gesellschaft, GTZ, Eschborn, Germany. 1998, 205-218.

[8] Tisdell C. Economic indicators to assess the sustainability of conservation farming projects: An evaluation. Journal of Agriculture, Ecosystems and Environment. 1996, Vol. 57, 117- 131.

[9] Smyth A.J., Dumanski J.K., Spendjian G., Swift M.J., Thorton P.K FESLM: An International Framework for Evaluating Sustainable Land Management. Land and Water Development Division, Food and Agriculture Organisation of the United Nations, Rome. World Soil Resources Reports. 1993, 73.

[10] Derpsch R., Friedrich T. Sustainable Crop Production Intensification: The adoption of Conservation Agriculture Worldwide, 16th ISCO Congress, Santiago. 2010.

[11] CFU. Conservation Farming and Conservation Agriculture Handbook for Hoe Farmers in Agro-ecological regions I and IIa. http://www.fsnnetwork.org/sites/default/files/conservation agriculture cf handbook for hoe farmers in Zambia. 2007.

[12] Cramb R., Garcia J.N., Gerrits R., Saguiguit G.C. Conservation Farming Projects in the Philippine Uplands: Rhetoric and Reality. 2000, World Development Vol. 28, No. 5, 911-927.
[13] Morris N.L., Miller P.C.H., Orson J.H., Froud-Williams R.J. The Adoption of Non-Inversion Tillage Systems in the United Kingdom and the Agronomic Impact on Soil, Crops and the Environment - a review. Journal of Soil Tillage and Research. 2010, Vol. 108, 1-15.

[14] FAO. Conservation Agriculture: Case studies in Latin America and Africa. Division of Land and Water Development, Food and Agricultural Organization, Rome. 2001, Soils Bulletin No. 76, 3-4.

[15] Dumanksi J., Peiretti R., Benites J.R., McGarry D., Pieri C. The Paradigm of Conservation Agriculture. Proceedings of the World Association for Soil Water Conservation. 2006, 58-64.

[16] Rockström J., Kaumbutho P., Mwalley J.N.A., Temesgen M., Mawenya L., Damgaard-Larsen S. Conservation Farming Strategies in East and Southern Africa: Yields and Rain Water Productivity from On-farm Action Research. Journal of Soil and Tillage Research. 2009, Vol. 103, 23-32.

[17] Blanco H., Lal R. Principles of Soil Conservation and Management. Springer, New York. 2009.

[18] Hobbs P.R., Sayre K., Gupta R. The Role of Conservation Agriculture in Sustainable Agriculture. Philosophical Transactions of the Royal Society. 2008, Vol. 363 (1491), 543-555.

[19] Bravo-Monroy L., Potts S., Tzanopoulos J. Drivers Influencing Farmer Decisions for Adopting Organic or Conventional Coffee Management Practices. Food policy. 2016, Vol. 58, 49-61.

[20] Overmars K.P., Verburg P.H. Analysis of Land Use Drivers at the Watershed and Household Level: Linking Two Paradigms at the Philippine Forest Fringe. International Journal of Geographical Information Science. 2005, Vol. 19, 125-152.

[21] Lefebvre H. The Production of Space. Blackwell, Oxford.1991.

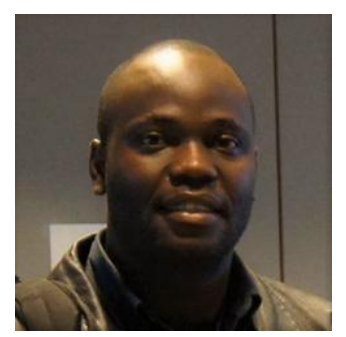

Mr. Joseph Thokozani Mwale is a Lecturer and Researcher at Mulungushi University (MU) in Kabwe, Zambia. He holds a Bachelor of Engineering Degree (1997-2004) of the University of Zambia, and a Master of Science Degree in Integrated Water Resources Management (2009-2010) of the University of Zimbabwe. Mr Mwale served as an Agricultural specialist in the Technical Services Branch of the Ministry of Agriculture from 2006 to 2011 before joining MU, where he is currently a Lecturer in the Department of Natural Resources. He specializes in water science and engineering for the optimum development and management of social-ecological systems. Mr Mwale's latest contribution to the body of knowledge is a journal article on Agriculture, Biofuels and Watersheds in the Water-Energy-Food Nexus: Governance Challenges at Local and Global Scales. Journal of Change and Adaptation in Social-Ecological Systems. 2015, Vol. 2, 93-95.

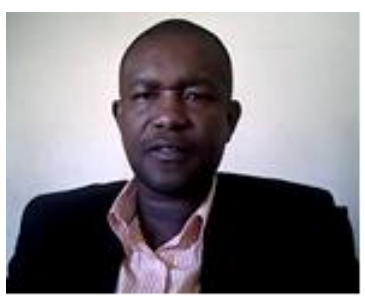

Mr. Idani Lichilo is an Agribusiness Lecturer and Researcher at Mulungushi University (MU) in Kabwe, Zambia. He obtained a Diploma in Agricultura Education at the Natural Resources Development College (NRDC) in 1992 and a Bachelor of Science in Agricultural Economics from the University of Zambia (UNZA) in 2003. He worked extensively as Secondary School Agriculture science teacher under the Ministry of Education before joining the then Ministry of Agriculture and Livestock where he was the District Agricultural Coordinator. Mr. Idani Lichilo was appointed Lecturer in the Department of Agriculture at MU in 2014. In pursuance of his academic path as a lecturer and researcher, he has taught several courses including Economics of Agricultural Markets, Agricultural project management, Agricultural Policy Analysis, Management of farm Enterprises, Management of Agricultural Cooperatives and Agricultural Development Economics at undergraduate level. He has also also been working and training small scale farmers around the university and elsewhere with agribusiness management skills in the market-oriented type of production.

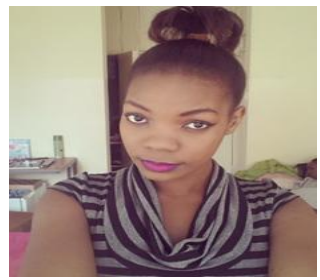

Mutinta Muyangwa is currently pursuing the Degree of Bachelor of Agriculture Programme in the School of Agriculture and Natural Resources at Mulungushi University, Zambia. 